\title{
EFIKASI DIRI TERHADAP KINERJA USAHA DENGAN KOMITMEN BERWIRAUSAHA SEBAGAI VARIABEL MEDIASI PADA UMKM
}

\author{
Titiek Ambarwati \\ Universitas Muhammadiyah Malang \\ ambarwati@umm.ac.id \\ Fika Fitriasari \\ Universitas Muhammadiyah Malang \\ fika@umm.ac.id
}

Abstract

This study aims to see the effect of self-efficacy on entrepreneurial commitment, entrepreneurial commitment on performance, the influence of self on business performance with entrepreneurial commitment as a mediating variable in MSMEs. This research was conducted on MSMEs in Malang. The type of research used is explanatory research that aims to test theories or research that reject or reject theories or reject the results of pre-existing research. Respondents in this study were 70 MSMEs owner in Malang. The data technique used a questionnaire. Determination of the number of samples using the Slovin formula, purposive sampling was used. Data analysis used Partial Least Square (PLS) using SmartPLS 3.0 software. The results showed a significant influence between self-efficacy and entrepreneurial commitment. Entrepreneurial commitment significantly affected business performance, self-efficacy had no direct effect on business performance, and entrepreneurial commitment had a mediating role between self-influence and business performance. Self-efficacy by business owners can increase entrepreneurial commitment and business performance. Although there is no direct interaction between self-efficacy and business performance, it is hoped that increasing the commitment to entrepreneurship can also improve business performance. The results of this study are used as suggestions for business owners to increase commitment in business, considering other entrepreneurial values.

Keywords: business performance; entrepreneurial commitment; self-efficacy.

\section{PENDAHULUAN}

Adanya tantangan global dan ketatnya persaingan tenaga kerja menyebabkan adanya pengangguran tak terkecuali di Indonesia. Pengangguran menjadi masalah utama di Indonesia karena adanya keterbatasan lapangan pekerjaan. Persaingan yang begitu ketat dalam bersaing dan seleksi pekerjaan sehingga banyaknya masyarakat mendapatkan pekerjaan yang kurang layak (Srimulyani, 2011). Faktor angka pengangguran yang meningkat di Indonesia dikarenakan masyarakat masih memprioritaskan untuk bekerja pada sector formal (Andika \& Madjid, 2012). Namun, seiring dengan berkembangnya teknologi dan bertambahnya informasi membuat masyarakat memilih untuk berwirausaha dengan membuka usaha dalam lingkup kecil (Herman, Hady, \& Arafah, 2018). Tanpa disadari, dengan adanya usaha-usaha tersebut, mampu membuka lapangan pekerjaan sehingga menekan tingginya angka pengangguran. UMKM merupakan suatu kegiatan ekonomi yang memiliki peranan penting pada perekonomian Indonesia (Putra, 2018). Menurut data Kementrian Koperasi dan Usaha Kecil dan Menengah (2018), kontribusi UMKM dalam penciptaan (PDB) pada tahun 2018 mencapai 14.038.598,5 (dalam milyar). Data Kementerian Koperasi dan UKM RI, menunjukkan bahwa UMKM secara keseluruhan mengalami perkembangan dan pertumbuhan yang baik seiring berganti tahun. Misalnya pada tahun 2014, total jumlah unit UMKM sebanyak 57,900,787. Data pada tahun terakhir, menunjukkan jumlah unit UMKM tersebut sudah mencapai angka 64.199.606. berdasarkan data tersebut, perkembangan UMKM di Indonesia juga semakin meningkat.

Keberhasilan suatu UMKM dapat terlihat dari adanya perkembangan yang selalu diberikan oleh UMKM dan berdampak pada kinerja UMKM (Herman et al., 2018). Kinerja UMKM akan meningkat apabila adanya koordinasi dan pengelolaan yang baik dari pengusaha maupun karyawan. Kinerja merupakan suatu pencapaian yang dilakukan oleh organisasi maupun individu dan tercapainya tujuan yang sudah ditetapkan sejak awal. Kinerja dapat dicapai dengan adanya kuantitas, kualitas, dan 
ketepatan waktu yang dilakukan (Mangkunegara, 2013). Selain itu, kinerja atau prestasi yang dicapai melalui kemampuan kreativitas dan inovasi dalam menghasil ide-ide atau produk-produk baru dihasilkan dari seseorang yang berorientasi pada efikasi diri, dan komitmen yang kuat. Efikasi diri atau self-efficacy merupakan penilaian tentang suatu kemampuan dalam menjalankan perilaku atau tujuan tertentu (Robbins \& Judge, 2015). Efikasi diri akan membantu dalam menentukan dan mencapai hasil yang diharapkan (Bandura, 2012). Baron \& Byrne (1987) menyatakan efikasi diri sebagai evaluasi seseorang terkait dengan kemampuan dan kompetensi dalam menyelesaikan suatu tugas, tujuan, dan mengatasi hambatan yang dihadapi dalam pengelolaan individua tau suatu organisasi. Dalam mendukung peningkatan dan perkembangan UMKM, maka dibutuhkan efikasi diri yang memiliki peranan penting dalam kesukesan suatu pekerjaan, yang dalam hal ini dikaitkan dengan kinerja usaha. Ahlin, Drnovšek, \& Hisrich (2014) menyatakan adanya peranan penting seperti efikasi diri mampu meningkatkan kesuksesan kinerja suatu usaha seperti UMKM. Adanya keyakinan dan memotivasi diri bahwa sanggup memberikan performa yang baik, akan berdampak pada kinerja usaha atau dalam hal ini UMKM. Selain itu, efikasi diri juga sebagai faktor pendorong yang menjadikan seseorang menjadi lebih giat dan optimal dalam melaksanaan pekerjaan. Penelitian ini memberikan informasi tentang efikasi diri, komitmen berwirausaha yang di terapkan para pengusaha UMKM Kota Malang dalam menghadapi persaingan.

Dalam mencapai kinerja yang optimal dan kuat, selain efikasi diri perlu adanya komitmen yang kuat, terutama dalam melaksanakan pekerjaan. Dengan adanya UMKM, maka komitmen untuk berwirausaha juga memiliki peranan penting dalam meningkatkan kinerja usaha. Menjadi wirausaha dan mencapai usaha yang sukses, dibutuhkan komitmen yang kuat, sehingga terciptanya fondasi yang kuat dalam menjalankan usaha, ketika memiliki komitmen yang tinggi, maka akan selalu berusaha dalam memajukan usaha (Rauf, 2020). Sahabudin (2012) menyatakan adanya pengaruh komitmen berwirausaha terhadap kinerja usaha. Komitmen yang tinggi ditunjukkan melalui kesediaan seseorang untuk menerima dan mempertahankan nilai-nilai dan tujuan kewirausahaan, yang didasarkan pada niat atau hasrat yang kuat, dorongan untuk bertindak, disiplin yang tinggi, dan keteguhan hati. (Carnahan, Agarwal, \& Campbell (2010) mengemukakan juga bahwa komitmen merupakan faktor yang sangat penting dalam pencapaian kinerja dan daya saing. Penelitian Emami \& Nazari (2012) menunjukkan bahwa komitmen memiliki pengaruh yang kuat terhadap kinerja usaha. Subhash et al. (2007) juga menyatakan pengaruh percaya diri (self esteem) dan komitmen berwirausaha terhadap kinerja, menemukan bahwa komitmen berwirausaha dan percaya diri memiliki pengaruh terhadap kinerja. Dengan mengkaitkan fenomena UMKM di Kota Malang dan beberapa tinjauan literatur, maka peneliti mengkaji lebih lanjut mengenai Efikasi Diri terhadap Kinerja Usaha dengan Komitmen Berwirausaha sebagai Mediasi. Adapun tujuan penelitian ini adalah menganalisis pengaruh efikasi diri terhadap kinerja usaha, efikasi diri terhadap komitmen berwirausaha, komitmen berwirausaha terhadap kinerja usaha dan dampak komitmen berwirausaha sebagai mediasi antara pengaruh efikasi diri terhadap kinerja usaha.

\section{KAJIAN PUSTAKA DAN PENGEMBANGAN HIPOTESIS}

\section{Efikasi Diri (Self-efficacy)}

Andika \& Madjid (2012) menyatakan efikasi diri merupakan suatu keyakinan atau kepercayaan diri individu mengenai kemampuannya untuk mengorganisasi, melakukan suatu tugas, mencapai suatu tujuan, menghasilkan sesuatu dan mengimplementasi tindakan untuk mencapai kecakapan tertentu. Bandura (2012) menyatakan bahwa efikasi diri mengacu pada kepercayaan individu akan kemampuannya untuk sukses dalam melakukan sesuatu. Efikasi diri merupakan keyakinan terhadap kemampuan dalam mengorganisasikan dan memunculkan perilaku yang dibutuhkan untuk menghasilkan kecakapan tertentu. Efikasi diri menurut Santrock (2007) adalah kepercayaan seseorang atas kemampuannya dalam menguasai situasi dan menghasilkan sesuatu yang menguntungkan. Niu (2010) menyebut efikasi diri adalah hasil interaksi antara lingkungan eksternal, mekanisme penyesuaian diri serta kemampuan personal, pengalaman dan pendidikan. Stipek (2001) dalam Santrock (2007) menjelaskan bahwa efikasi diri adalah kepercayaan seseorang atas kemampuannya sendiri. Dalam berwirausaha, efikasi memiliki peranan dalam kemajuan usaha. Dengan memiliki 
Titiek Ambarwati \& Fika Fitriasari. Efikasi Diri terhadap Kinerja Usaha dengan Komitmen Berwirausaha sebagai Variabel Mediasi pada UMKM

efikasi diri pada pemilik usaha, Wirama \& Wulanyani (2016) menyatakan seseorang dapat memulai mengubah keadaan hidupnya dengan mengubah dirinya terlebih dahulu sehingga dengan informasi tentang diri merupakan langkah awal dalam meningkatkan efikasi diri.

\section{Komitmen Berwirausaha}

Komitmen memiliki peranan dalam keberlangsungan organisasi. Komitmen organisasi merupakan sikap mengenal dan terikat pada suatu organisasi (Moorhead \& Griffin, 2013). Komitmen tidak hanya dalam lingkup organisasional saja, tetapi juga dalam berwirausaha. Secara umum, komitmen adalah perjanjian (keterikatan) untuk melakukan sesuatu. Bila dikaitkan dengan berwirausaha, maka pemilik usaha memiliki keterikatan diri dan keinginan yang kuat dalam membangun usaha dan memajukan keberadaan usahanya (Rauf, 2020). Komitmen sendiri dapat terbentuk dari diri sendiri dimana memiliki keinginan yang kuat untuk selalu maju (Darmawan, 2020). Namun, faktor utama yang membuat orang tidak dapat mempertahankan komitmen yang telah dibuat sebelumnya, yaitu internal (diri sendiri) maupun Eksternal (di luar diri sendiri). Untuk membangun komitmen dalam berwirausaha diperlukan kekuatan pribadi setiap wirausaha, contohnya kesabaran dan ketabahan; keinginan keras untuk maju; keyakinan kuat untuk maju; keuletan dan ketekunan; pemikiran yang kreatif dan konstruktif; ketahanan mental dan fisik; tanggung jawab dan jujur (Rusdiana, 2018).

\section{Kinerja Usaha}

Kinerja identik dengan kinerja karyawan di mana pencapaian yang dilakukan oleh karyawan. Kinerja menjadi tolak ukur dalam pencapaian organisasi. Kinerja merupakan ukuran keberhasilan sebuah perusahaan dalam mencapai tujuannya. Kinerja positif menunjukkan bahwa perusahaan dapat mencapai tujuan perusahaan, sebaliknya kinerja yang negatif berarti perusahaan tidak dapat mencapai tujuannya. Ukuran kinerja organisasi dapat berbentuk kuantitatif maupun kualitatif. Kinerja merupakan suatu kondisi yang harus diketahui dan dikonfirmasikan kepada pihak tertentu untuk mengetahui tingkat pencapaian hasil suatu instansi dihubungkan dengan visi yang diemban suatu organisasi atau perusahaan serta mengetahui dampak positif dan negatif dari suatu kebijakan operasional (Lubis, Anurogo, \& Pamungkas, 2018). Najib \& Kiminami (2011) melakukan pengukuran kinerja bisnis UKM dengan menggunakan metode pengukuran subyektif meliputi volume penjulan, profitabilitas dan pangsa pasar.

\section{Hubungan antar Variabel}

Efikasi diri juga dikenal dengan teori kognitif sosial atau penalaran sosial yang merujuk pada keyakinan individu bahwa dirinya mampu dalam menjalankan aktivitasnya (Robbins \& Judge, 2015). Dengan adanya keyakinan yang kuat dan mampu dalam menjalankan tugasnya, maka akan semakin meningkatkan komitmen. Komitmen merupakan keterikatan dalam suatu hal atau tugas yang akan dilaksanakan dengan prinsip-prinsip yang dianut (Rauf, 2020). Intan (2017) menjelaskan adanya pengaruh signifikan antara efikasi diri terhadap komitmen berwirausaha. Baggerly, et al. (2006) menemukan bahwa efikasi diri yang tinggi berpengaruh signifikan terhadap komitmen berwirausaha. Demikian juga hasil penelitian De Clercq, Benson, \& Martin (2012) menemukan efikasi diri wirausahawan berpengaruh positif terhadap komitmen berwirausaha. Berdasarkan penelitian tersebut dikemukakan bahwa efikasi diri memiliki pengaruh positif yang signifikan terhadap komitmen berwirausaha.

H1: Efikasi diri berpengaruh signifikan terhadap komitmen berwirausaha.

Komitmen berwirausaha memiliki peranan penting dalam keberlangsungan usaha. Tanpa adanya komitmen yang kuat, maka usaha yang dijalankan tidak dapat mencapai tujuan yang diinginkan dan tidak adanya pencapaian dalam kinerja usaha. Kinerja usaha dapat ditunjukkan dengan meningkatnya volume penjualan, profit yang didapatkan dan beberapa factor yang mendukung untuk menghasilkan kinerja usaha yang meningkat (Najib \& Kiminami, 2011). Sahabudin (2012) menjelaskan bahwa komitmen berwirausaha berpengaruh terhadap kinerja usaha rumput laut berskala kecil. Komitmen yang tinggi ditunjukkan melalui kesediaan seseorang untuk menerima dan mempertahankan nilai-nilai dan tujuan kewirausahaan yang didasarkan pada niat atau hasrat yang kuat, dorongan untuk bertindak, disiplin yang tinggi, dan keteguhan hati. Sehingga, komitmen yang kuat dapat mengarahkan perilaku 
seseorang untuk menghasilkan kinerja atau prestasi. Carnahan et al. (2010) mengemukakan bahwa komitmen merupakan faktor yang sangat penting dalam pencapaian kinerja dan daya saing. Hasil penelitian Emami \& Nazari (2012) menunjukkan bahwa komitmen memiliki pengaruh yang kuat terhadap kinerja usaha. Selanjutnya Subhash et al. (2007) mengkaji pengaruh percaya diri (self esteem) dan komitmen berwirausaha terhadap kinerja menemukan bahwa komitmen berwirausaha dan percaya diri memiliki pengaruh terhadap kinerja.

H2: Komitmen berwirausaha berpengaruh signifikan terhadap kinerja usaha.

Efikasi diri merupakan keyakinan atau kepercayaan diri dalam mencapai tujuan tertentu (Bandura, 2012), juga sebagai bentuk penilaian diri apakah dapat melakukan sesuai dengan yang diharapkan (Alwisol, 2010). Dengan memiliki efikasi diri yang tinggi, maka akan semakin tertantang dan melakukan kinerja semaksimal mungkin dan mencapai kinerja usaha yang tinggi. Efikasi diri merupakan keyakinan kuat yang dimiliki oleh pemilik usaha dalam mencapai tujuan tertentu. Dengan adanya keyakinan yang kuat, maka akan berdampak pada kinerja yang dicapai. Purnomo \& Lestari (2010) menemukan adanya pengaruh signifikan antara efikasi diri terhadap kinerja usaha. Arsanti (2009) juga menemukan adanya pengaruh positif antara self-efficacy terhadap kinerja usaha.

H3: Efikasi diri berpengaruh signifikan terhadap kinerja usaha.

Efikasi diri merupakan factor penting dalam berwirausaha, terlebih dalam kinerja usaha. (Utari \& Sukidjo, 2020). Dengan adanya keyakinan dan kemampuan yang baik, maka akan melakukan perencanaan yang baik dalam menjalankan bisnis dan berdampak pada kinerja. Penelitian Mair \& Noboa (2005) terhadap 220 manajer menengah dengan mengkaji pengaruh efikasi diri terhadap perilaku wirausahawan dalam meningkatkan kinerja menemukan bahwa efikasi diri merupakan prediktor dari perilaku yang memiliki pengaruh terhadap kinerja usaha. Tidak hanya menjadi dorongan untuk melakukan sesuatu, namun juga berani dalam mengambil resiko dan bertanggungjawab dalam berwirausaha (Wartiovaara, Lahti, \& Wincent, 2019). Efikasi diri dapat mempengaruhi kinerja usaha melalui sikap dan perilaku melalui tindakan-tindakan yang berorientasi pada pencapaian prestasi atau kinerja dengan memanfaatkan kemampuan yang dimiliki. Sahabuddin (2018) menujukkan bahwa efikasi diri berpengaruh secara tidak langsung terhadap kinerja usaha rumput laut berskala kecil melalui komitmen berwirausaha. Dengan adanya keyakinan yang kuat dalam mencapai sebuah tujuan, maka akan memperkuat dan meningkatkan komitmen berwirausaha, dengan mengikatkan diri pada kegiatan usaha, yang berdampak baik pada kinerja usaha.

H4: Komitmen berwirausaha memediasi pengaruh efikasi diri terhadap kinerja usaha.

Berdasarkan kajian literatur dan hipotesis, kerangka konsep pada penelitian ini dapat dilihat di Gambar 1.

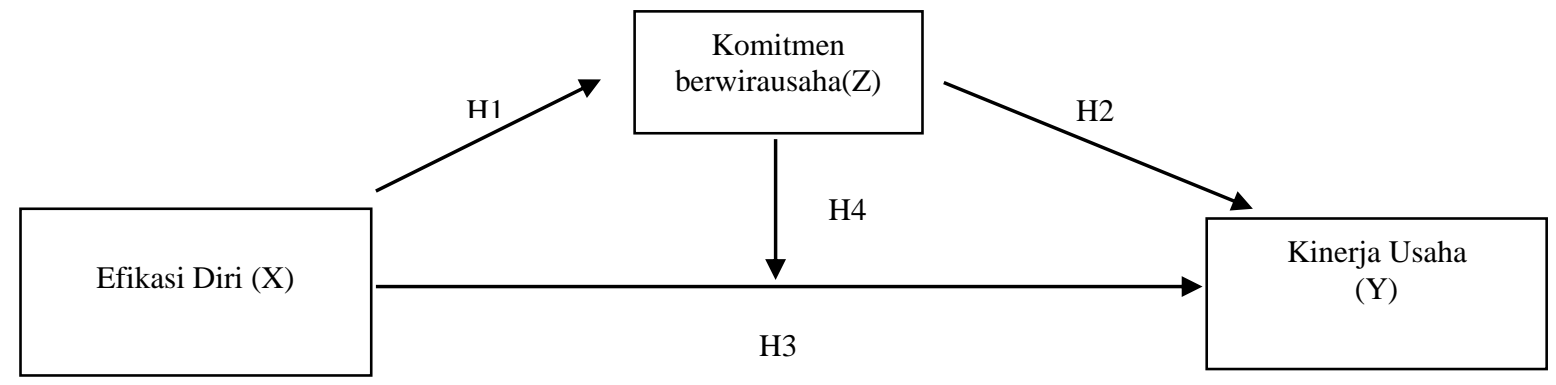

Gambar 1. KERANGKA KONSEPTUAL 
Titiek Ambarwati \& Fika Fitriasari. Efikasi Diri terhadap Kinerja Usaha dengan Komitmen Berwirausaha sebagai Variabel Mediasi pada UMKM

\section{METODE PENELITIAN}

Penelitian ini termasuk dalam jenis penelitian research yaitu penelitian bertujuan untuk menguji suatu teori atau hipotesis guna memperkuat atau bahkan menolak teori atau hipotesis hasil penelitian yang sudah ada sebelumnya. Penelitian ini dilaksanakan di Kota Malang khususnya di Kecamatan Lowokwaru pada pengusaha UMKM dengan jumlah responden 70 pengusaha UMKM. Definisi Operasional Variabel pada penelitian ini adalah: Efikasi Diri (X) adalah kepercayaan seseorang atas kemampuannya dalam menguasai situasi dan menghasilkan sesuatu yang dapat berupa: kesanggupan kerja, ketegasan dalam penyelesaian tugas dan kesediaan menerima tantangan; Komitmen Berwirausaha $(Z)$ suatu keterikatan diri dan keinginan yang kuat untuk membangun,memajukan,dan mempertahankan keberadaan usahanya dalam situasi apapun; Kinerja Usaha (Y) yaitu hasil kerja secara seseorang dalam melaksanakan usaha dapat berupa Profitabilitas, Kemampuan untuk menghasilkan laba pada presentase tertentu, Pangsa Pasar yaitu Jangkauan pasar yang dimiliki, Proses Bisnis serta Pertumbuhan dan pembelajaran seperti Kesejahteraan karyawan, Pengalaman Karyawan.

Populasi dari penelitian ini adalah seluruh pengusaha UMKM yang berada di Kota Malang Khususnya di Kecamatan Lowokwaru berjumlah 771 pengusaha. Teknik pengambilan sampel dengan menggunakan slovin dengan tingkat eror $10 \%$ sehingga jumlah sampel yang digunakan adalah 70 pengusaha UMKM. Teknik pengambilan sampel dengan menggunakn purposive sampling. Teknik analisis data menggunakan analisis jalur (path analysis) dengan software SmartPLS 3.0

\section{HASIL DAN PEMBAHASAN}

\section{Hasil Uji Validitas dan Reliabilitas}

Penelitian ini menguji validitas dan reliabilitas yang dijabarkan pada Tabel 1 berikut. Berdasarkan Tabel 1, nilai AVE pada masing-masing variabel memiliki nilai lebih dari 0.5 dan memenuhi persyaratan. Nilai Cronbach's Alpha masing-masing variabel juga memiliki nilai lebih besar dari 0.7 sehingga semua konstruk dari variabel tersebut dikatakan reliablel. Hasil Composite Reliability masing-masing variabel juga memiliki nilai lebih besar dari 0.7 sehingga dinyatakan reliabel (Ghozali \& Latan, 2015).

Tabel 1.

PENGUJIAN AVE, CRONBACH'S ALPHA, DAN COMPOSITE RELIABILITY

\begin{tabular}{ccccc|}
\hline Variabel & AVE & Cronbach's Alpha & Composite Reliability & Keterangan \\
\hline Efikasi Diri & 0.572 & 0.878 & 0.903 & Reliabel \\
Komitmen Berwirausaha & 0.656 & 0.924 & 0.938 & Reliabel \\
Kinerja Usaha & 0.549 & 0.879 & 0.905 & Reliabel \\
\hline
\end{tabular}

Sumber: Data diolah, 2020

\section{Hasil Uji Goodness of Fit Model}

Pengujian goodness of fit model dapat dilihat dari nilai predictive-relevance $\left(\mathrm{Q}^{2}\right)$. Nilai $\mathrm{Q}^{2}$ dihitung berdasarkan nilai $\mathrm{R}^{2}$ dari masing-masing variabel endogen. Ghozali dan Latan (2015) menentukan kriteria kuat atau lemah sebuah model berdasarkan $Q^{2}$ adalah sebagai berikut: jika nilai $Q^{2} 0.35$ maka termasuk model kuat, jika nilai $\mathrm{Q}^{2} 0.15$ maka termasuk model moderat, dan jika nilai $\mathrm{Q}^{2} 0.02$ maka termasuk model lemah.

Pengukuran variabel endogen komitmen berwirausaha memiliki nilai $\mathrm{R}^{2}$ sebesar 0.282 . Pengukuran variabel endogen kinerja usaha diperoleh nilai $\mathrm{R}^{2}$ sebesar 0.640 . Dengan demikian nilai predictiverelevance $\left(\mathrm{Q}^{2}\right)$ diperoleh dalam formula (1). Berdasarkan perhitungan (1), didapatkan nilai $\mathrm{Q}^{2}$ sebesar 0.741 atau sehingga model struktural yang terbentuk dikatakan sangat baik karena mendekati nilai 1 . Model variasi variabel dalam penelitian ini sebesar $74.1 \%$ dan sisanya $25.9 \%$ dijelaskan oleh variabel lain dan eror.

$\mathrm{Q}^{2}=1-\left(1-\mathrm{R}_{1}^{2}\right)\left(1-\mathrm{R}_{2}^{2}\right)=1-(1-0.282)(1-0.640)=0.741$ 
Penelitian ini dilakukan di UMKM Kota Malang di kecamatan Lowokwaru. Kota Malang khususnya kecamatan Lowokwaru memiliki beragam jenis UMKM mulai dari makanan, minuman, hingga crafting atau kerajinan tangan. Jumlah UMKM yang menjadi responden pada penelitian ini adalah 70 pengusaha UKM. Karakteristik responden berdasarkan jenis kelamin didominasi oleh Perempuan sebanyak 63 orang dan laki-laki sebanyak 7 orang. Mayoritas UMKM berfokus untuk memberdayakan Ibu Rumah Tangga (IRT) yang tidak bekerja sehingga memiliki penghasilan tambahan. Masa kerja dan berdirinya UKM didominasi sejak 5 tahun hingga sekarang. Melihat perkembangan UMKM dan banyaknya peluang usaha, menyebabkan adanya keberadaan UMKM tersebar dan meningkatkan perekonomian. Hasil dari analisis data menjelaskan pengaruh antara efikasi diri terhadap kinerja usaha secara langsung maupun tidak langsung melalui mediasi ditunjukkan pada Gambar 1 berikut.

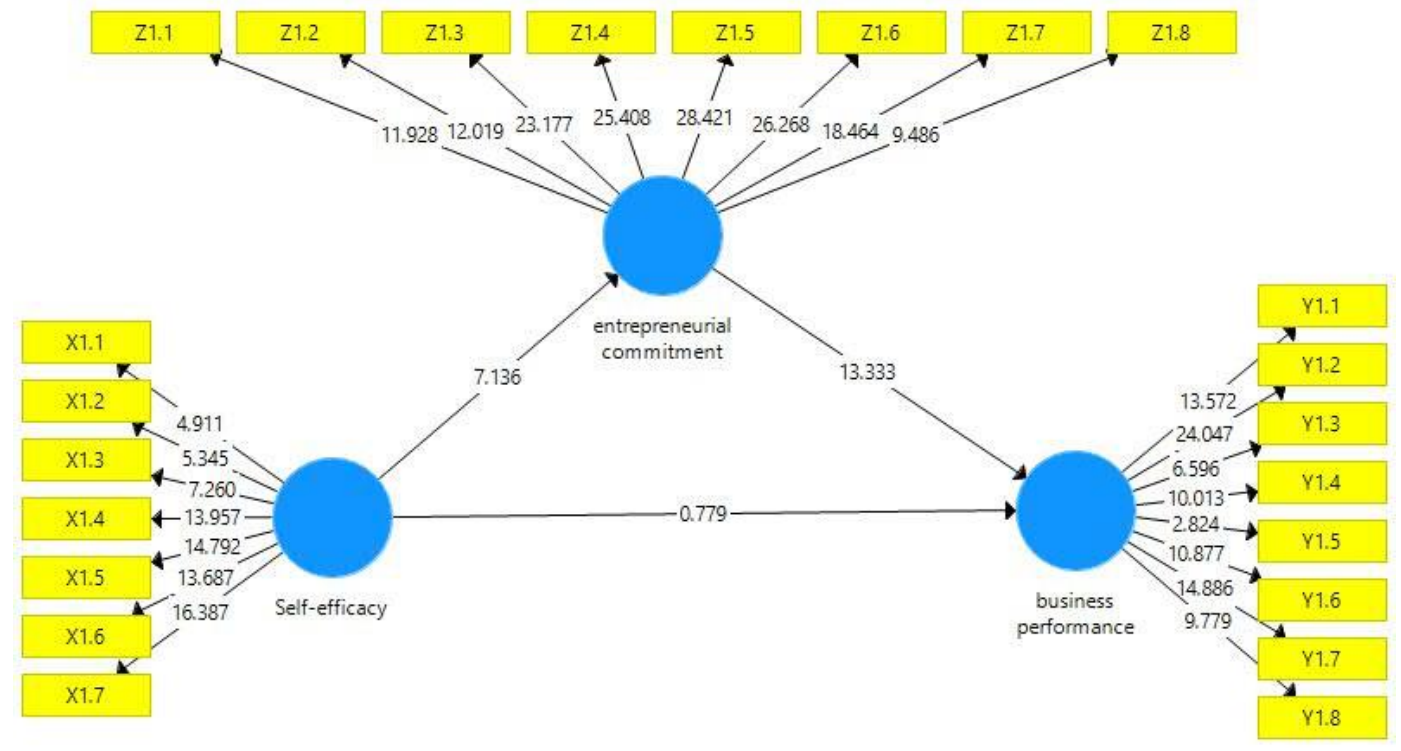

Sumber: Data diolah (2020)

\section{Gambar 1. HASIL ANALISIS DATA PATH ANALYSIS MENGGUNAKAN SMARTPLS 3.0}

Hasil uji statistik pengaruh langsung disajikan pada Tabel 2. Hasil pengujian pengaruh langsung antara efikasi diri terhadap komitmen berwirausaha diperoleh nilai t-statistik 7.136 dan p-value 0.000. karena nilai t-statistik 7.136>1.96 dan p-value $0.000<0.05$ maka efikasi diri berpengaruh signifikan terhadap komitmen berwirausaha, sehingga $\mathrm{H} 1$ yang menyatakan bahwa efikasi diri berpengaruh signifikan terhadap komitmen berwirausaha diterima. Hasil pengujian pada hipotesis 2 yaitu pengaruh komitmen berwirausaha terhadap kinerja usaha diperoleh nilai t-statistik $>1.96$ yaitu 13.333 dengan $p-$ value 0.000 sehingga komitmen berwirausaha berpengaruh signifikan terhadap kinerja usaha dan $\mathrm{H} 2$ diterima. Hasil pengujian langsung berikutnya adalah pengaruh efikasi diri terhadap kinerja usaha. Hasil menunjukkan t-statistik $0.779<1.96$ dan p-value $0.437>0.05$ maka efikasi diri tidak berpengaruh signifikan terhadap kinerja usaha sehingga $\mathrm{H} 3$ ditolak.

Tabel 2.

HASIL ANALISIS PENGARUH LANGSUNG

\begin{tabular}{cccccc}
\hline Hipotesis & Variabel Bebas & Variabel Terikat & t Statistik & p-value & Keterangan \\
\hline 1 & Efikasi diri & Komitmen & 7.136 & 0.000 & Signifikan \\
& & berwirausaha & & & \\
2 & Komitmen berwirausaha & Kinerja usaha & 13.333 & 0.000 & Signifikan \\
3 & Efikasi diri & Kinerja usaha & 0.779 & 0.437 & Tidak Signifikan \\
\hline
\end{tabular}

Sumber: Data diolah (2020) 
Titiek Ambarwati \& Fika Fitriasari. Efikasi Diri terhadap Kinerja Usaha dengan Komitmen Berwirausaha sebagai Variabel Mediasi pada UMKM

Tabel 3.

HASIL SOBEL TEST

\begin{tabular}{cccccccc}
\hline Jalur & $\mathbf{A}$ & $\mathbf{B}$ & $\mathbf{S E}_{\mathbf{A}}$ & $\mathbf{S E}_{\mathbf{B}}$ & t hitung & Sig & Keterangan \\
\hline ED-KB-KU & 0.541 & 0.770 & 0.076 & 0.058 & 6.273 & 0.000 & sig \\
\hline Sumber:
\end{tabular}

Sumber: Data diolah (2020)

Berdasarkan hasil analisis Sobel Test pada Tabel 3, diketahui nilai sobel test sebesar $6.273>1.96$ dan signifikansi $0.000<0.05$ sehingga komitmen berwirausaha memediasi efikasi diri terhadap kinerja usaha. Hasil analisis menunjukkan bahwa pengaruh variabel efikasi diri terhadap komitmen berwirausaha dan pengaruh komitmen berwirausaha terhadap kinerja usaha memiliki hasil signifikan sedangkan untuk pengaruh langsung efikasi diri terhadap kinerja usaha tidak signifikan. Sehingga komitmen berwirausaha dalam penelitian ini dikatakan sebagai variabel mediasi sempurna (complete mediation). Ini berarti $\mathrm{H} 4$ diterima.

\section{Pengaruh Efikasi Diri terhadap Komitmen Berwirausaha}

Efikasi diri (self-efficacy) merupakan suatu keyakinan atau kepercayaan diri individu menghasilkan sesuatu dan mengimplementasi tindakan untuk mencapai kecakapan tertentu. Efikasi diri diperlukan dalam sebuah organisasi dalam mencapai visi, misi serta tujuan yang telah disepakati dan dibentuk oleh organisasi. Hasil penelitian menunjukkan adanya pengaruh signifikan antara efikasi diri terhadap komitmen berwirausaha. Komitmen berwirausaha memiliki peranan penting dalam keberlangsungan UKM. adanya kepercayaan pada diri sendiri dan motivasi untuk selalu melakukan yang tebaik bagi UKM merupakan salah satu langkah awal dalam memberikan kesempatan dan peluang berhasil pada berwirausaha. Komitmen yang dijalankan dalam menekuni berwirausaha didasarkan adanya keinginan untuk berhasil pada UKM. Hasil penelitian ini sejalan dengan penelitian Baggerly, et al. (2006) dan Fortune et al. (2005) yang menemukan bahwa efikasi diri yang tinggi berpengaruh signifikan terhadap komitmen berwirausaha. Efikasi diri memunculkan sikap keyakinan terhadap suatu kemampuan dan keberhasilan yang ingin dicapai. Di sisi lain, komitmen juga menjadi peranan penting dalam sebuah keberhasilan dimana keinginan kuat dalam mempertahankan nilai dan tujuan yang ingin dicapai. Semakin tinggi efikasi diri, maka akan semakin kuat komitmen yang dijalankan Purnomo \& Lestari (2010).

\section{Pengaruh Komitmen Berwirausaha terhadap Kinerja Usaha}

Hasil penelitian menunjukkan adanya pengaruh yang signifikan antara komitmen berwirausaha terhadap kinerja usaha. Artinya, semakin kuat nilai dan keyakinan dalam mempertahankan nilai dan tujuan sebuah usaha, maka akan semakin tinggi usaha yang akan diberikan. Kinerja usaha dapat ditunjukkan dengan meningkatnya volume penjualan, profit yang didapatkan dan beberapa factor yang mendukung untuk menghasilkan kinerja usaha yang meningkat (Najib \& Kiminami, 2011). Hal tersebut dapat ditunjukkan dengan adanya semangat dalam melakukan pengembangan dan terus melakukan yang terbaik sehingga berdampak pada kinerja sebuah usaha. Hasil penelitian ini sejalan dengan Emami \& Nazari (2012) yang menjabarkan adanya pengaruh langsung antara komitmen berwirausaha terhadap kinerja usaha. Hasil ini sejalan dengan penelitian yang dilakukan oleh Sahabudin (2012) yang menemukan adanya komitmen yang tinggi pada usaha akan memberikan dampak bagi kinerja UMKM sehingga komitmen wirausaha memiliki pengaruh signifikan terhadap kinerja UMKM.

\section{Pengaruh Efikasi Diri terhadap Kinerja Usaha}

Hasil penelitian menunjukkan tidak adanya pengaruh efikasi diri terhadap kinerja usaha. Semakin tinggi atau semakin diterapkan efikasi diri yang dimiliki oleh organisasi, maka akan tidak berdampak pada kinerja usaha yang dilakukan oleh karyawan UKM. Penelitian ini sejalan dengan Sahabudin (2012) yang menyatakan adanya tidak adanya peran efikasi diri dalam peningkatan kinerja usaha. Hal ini menjelaskan bahwa belum semua UMKM maupun pengusaha UKM menyadari pentingnya efikasi diri dalam pencapaian maupun peningkatan kinerja usaha. Sikap efikasi diri juga perlu ditinjau dari sisi individu itu sendiri, apakah sikap maupun perilaku yang akan dilakukan sudah tepat pada UKM yang dikelola dan dalam pengembangannya sehingga berdampak pada kinerja usaha. Selain itu jika 
ada keyakinan diri saja tanpa ada usaha untuk melakukan perbaikan maupun pengembangan, maka tidak akan berdampak pada kinerja usaha. Berbanding terbalik dengan hasil penelitian Ahlin, Drnovšek, \& Hisrich (2014) menyatakan adanya peranan penting seperti efikasi diri mampu meningkatkan kesuksesan kinerja suatu usaha seperti UMKM. Adanya keyakinan dan memotivasi diri bahwa sanggup memberikan performa yang baik, akan berdampak pada kinerja usaha atau dalam hal ini UMKM.

\section{Pengaruh Efikasi Diri terhadap Kinerja Usaha Dimediasi oleh Komitmen Berwirausaha}

Penelitian ini menggunakan komitmen berwirausaha sebagai mediasi antara pengaruh efikasi diri terhadap kinerja usaha. Hasil menunjukkan bahwa komitmen berwirausaha menjadi peran mediasi atau variable intervening ditinjau dari hasil uji sobel tes. Hal ini menunjukkan adanya efikasi diri pada pengusaha UMKM yaitu berkeyakinan memiliki hasil yang baik, didukung dengan adanya komitmen yang kuat untuk berwirausaha, sehingga meningkatkan kinerja usaha. Semakin meningkatnya efikasi diri dan diterapkan dengan baik oleh pelaku usaha, maka akan meningkatkan komitmen berwirausaha dan berdampak baik pula pada kinerja usaha. Dalam meningkatkan kinerja umkm bisa dipengaruhi langsung dari nilai-nilai kewirausahaan, dalam hal ini efikasi diri, atau bisa juga efikasi diri akan meningkatkan komitmen berwirausaha terlebih dahulu pada pelaku usaha dan berdampak pada kinerja usaha. Hasil pengujian mediasi ini menjadikan komitmen berwirausaha sebagai full mediation atau mediasi penuh. Penelitian ini sejalan dengan penelitian Sahabudin (2012) yang menyatakan efikasi diri berpengaruh tidak langsung terhadap kinerja usaha melalui komitmen berwirausaha. Komitmen berwirausaha ditunjukkan dengan kesediaan seseorang untuk menerima dan mempertahankan nila dan tujuan usaha yang didirikan yang didasarkan pada niat berwirausaha.

\section{KESIMPULAN}

Kesimpulan pada penelitian ini adalah sebagai berikut: efikasi diri berpengaruh terhadap komitmen berwirausaha. Dengan adanya keyakinan yang kuat dan percaya diri maka akan meningkatkan keterikatan dan keinginan kuat di dalam berwirausaha. Komitmen berwirausaha berpengaruh signifikan terhadap kinerja usaha. Dengan adanya keinginan yang kuat dalam berwirausaha, maka akan meningkatkan kinerja usaha. Dengan adanya komitmen berwirausaha, maka akan berdampak pada kemajuan dan keberlangsungan UMKM. Efikasi diri tidak berpengaruh signifikan terhadap kinerja usaha. Adanya keyakinan untuk mencapai tujuan tanpa adanya keterlibatan dalam usaha, maka tidak akan memiliki dampak pada kinerja usaha. Komitmen berwirausaha memiliki peran mediasi pada pengaruh efikasi diri terhadap kinerja usaha. Memiliki keyakinan dan kepercayaan diri untuk berhasil dalam mencapai tujuan usaha, maka semakin tinggi pula komitmen atau keterikatan kepada nilai yang dipegang untuk keberhasilan usaha, maka memiliki dampak pula pada kinerja usaha yang semakin tinggi. UMKM di Kota Malang perlu adanya penanaman efikasi diri yang kuat dan diimbangi dengan adanya komitmen berwirausaha yang kuat untuk keberlangsungan UMKM. Adanya pengaruh tidak signifikan antara efikasi diri terhadap kinerja usaha, namun dapat berpengaruh secara tidak langsung melalui mediasi sehingga dapat dikaji kembali pada penelitian selanjutnya dengan menambah variable lain, seperti niat berwirausaha pada pengusaha UMKM dan meninjau dari sisi kinerja karyawannya. Selain itu, peneliti selanjutnya dapat mengembangkan objek yang tidak hanya pada satu kecamatan saja, tapi bisa dikembangkan lebih luas kembali serta dapat menguji melalui uji moderasi dengan melibatkan variabel inovasi maupun strategi yang digunakan dalam bisnis.

\section{DAFTAR PUSTAKA}

Ahlin, B., Drnovšek, M., \& Hisrich, R. D. (2014). Entrepreneurs' creativity and firm innovation: the moderating role of entrepreneurial self-efficacy. Small Business Economics, 43(1), 101-117.

Alwisol. (2010). Psikologi Kepribadian. Malang: UMM Press.

Andika, M., \& Madjid, I. (2012). Analisis Pengaruh Sikap, Norma Subyektif dan Efikasi Diri terhadap Intensi Berwirausaha pada Mahasiswa Fakultas Ekonomi Universitas Syiah Kuala. Eco 
Titiek Ambarwati \& Fika Fitriasari. Efikasi Diri terhadap Kinerja Usaha dengan Komitmen Berwirausaha sebagai Variabel Mediasi pada UMKM

Entrepreneurship Seminar \& Call for Paper "improving Performance by Improving Environment," 190-197.

Arsanti, T. A. (2009). Hubungan antara penetapan tujuan,. Jurnal Bisnis dan Ekonomi (JBE), 16(2), 97-110.

Bandura, A. (2012). On the functional properties of perceived self-efficacy revisited. Journal of Management, 38, 9-44.

Baron, R. A., \& Byrne, D. (1987). Social psychology: Understanding human interaction. Boston: Allyn \& Bacon.

Carnahan, S., Agarwal, R., \& Campbell, B. (2010). The Effect of Firm Compensation Structures on the Mobility and Entrepreneurship of Extreme Performers. Business, 902(December 2009), 143. https://doi.org/10.1002/smj

Darmawan, D. (2020). Profesionalisme, Motivasi Berprestasi, Komitmen Organisasi Dan Pengaruhnya Terhadap Intensi Berwirausaha. EKUITAS (Jurnal Ekonomi dan Keuangan), 3(3), 344-364. https://doi.org/10.24034/j25485024.y2019.v3.i3.4167

De Clercq, D., Benson, H., \& Martin, B. (2012). The roles of learning orientation and passion for work in the formation of entrepreneurial intention. International Small Business Journal, 1-25.

Emami, M., \& Nazari, K. (2012). Entrepreneurship, Religion, and Business Ethics. Australian Journal of Business and Management Research, 1(11), 59-69.

Fortune, A. E., Mingun, L., \& Cavazos, A. (2005). Achievement Motivation And Outcome In Social Work Field Education. Journal of Social Work Education, 41(1), 13-27. https://doi.org/10.5175/JSWE.2005.200202122

Ghozali, I., \& Latan, H. (2015). Partial Least Square: Konsep, Teknik, dan Aplikasi menggunakan Program SmartPLS 3.0. Semarang: Badan Penerbit Undip.

Herman, H., Hady, H., \& Arafah, W. (2018). The Influence of Market Orientation and Product Innovation on the Competitive Advantage and Its Implication toward Small and Medium Enterprises (Ukm) Performance. International Journal of Science and Engineering Invention, 4(08), 8-21. https://doi.org/10.23958/ijsei/vol04-i08/02

Intan, G. A. (2017). Pengaruh Self Efficacy dan Motif Berprestasi Terhadap Kinerja Agen Pemasaran Asuransi Equity Life Indonesia Cabang Renon Denpasar. E-Jurnal Ekonomi dan Bisnis Universitas Udayana, 6(4), 1547-1574.

Kementrian Koperasi dan Usaha Kecil dan Menengah. (2018). Perkembangan Data Usaha Mikro, Kecil, Menengah (UMKM) Dan Usaha Besar (UB) Tahun 2017 - 2018. Diambil 12 Agustus 2020, dari https://www.kemenkopukm.go.id/uploads/laporan/1580223129_PERKEMBANGAN DATA USAHA MIKRO, KECIL, MENENGAH (UMKM) DAN USAHA BESAR (UB) TAHUN 2017 - 2018.pdf

Lubis, M. Z., Anurogo, W., \& Pamungkas, D. S. (2018). Pemberdayaan Masyarakat Nongsa dengan Pembelajaran Penentuan Daerah Penangkapan Ikan Berbasis Teknologi di Bidang Kelautan. Jurnal Pengabdian Kepada Masyarakat, 4(1), 11-18.

Mair, J., \& Noboa, E. (2005). Social Entrepreneurship: How Intentions to Create a Social Enterprise Get Formed. SSRN Electronic Journal, 3(521), 1-20. https://doi.org/10.2139/ssrn.462283 
Mangkunegara, A. P. (2013). Manajemen Sumberdaya Manusia Perusahaan. Bandung: PT. Remaja.

Moorhead, G., \& Griffin, R. . (2013). Perilaku Organisasi. Jakarta: Salemba Empat.

Najib, M., \& Kiminami, A. (2011). Innovation, cooperation and business performance: Some evidence from Indonesian small food processing cluster. Journal of Agribusiness in Developing and Emerging Economies, 1(1), 75-96. https://doi.org/10.1108/20440831111131523

Niu, H. (2010). Investigating the effects of selfefficacy on foodservice industry employees \& rsquo; career commitment. International Journal of hospitality Management, 29(1336), 743-750.

Purnomo, R., \& Lestari, S. (2010). Pengaruh Kepribadian, Self-Efficacy, Dan Locus of Control Terhadap Persepsi Kinerja Usaha Skala Kecil Dan Menengah. Jurnal Bisnis dan Ekonomi (JBE), $17(2), 144-160$.

Putra, A. H. (2018). Peran UMKM Dalam Pembangunan Dan Kesejahteraan Masyarakat Kabupaten Blora. Jurnal Analisa Sosiologi, 5(2). https://doi.org/10.20961/jas.v5i2.18162

Rauf, R. (2020). Pengaruh Karakteristik Individu Dan Komitmen Berwirausaha Terhadap Kinerja Usaha Penangkapan Ikan Laut. SEIKO: Journal of Management \& Business, 3(2), 92-100. https://doi.org/10.37531/sejaman.v3i2.594

Robbins, S. P., \& Judge, T. A. (2015). Perilaku Organisasi. Jakarta: Salemba Empat.

Rusdiana. (2018). Kewirausahaan Teori dan Praktik. Bandung: Pustaka Setia.

Sahabuddin, R. (2018). Effect of entrepreneurship commitment to self-efficacy through intention of entrepreneurship and competence. International Journal of Business and Management Science, $8(1), 67-81$.

Sahabudin, R. (2012). Perkembangan Nilai-Nilai Kewirausahaan dalam Meningktakan Kinerja Usaha Rumput Laut Skala Kecil. Trikonomika, 11(1), 81-95.

Santrock, J. W. (2007). Remaja. Jakarta: Erlangga.

Srimulyani, V. A. (2011). kajian Faktor-Faktor Motivasi yang Berpengaruh terhadap Minat Berwirausaha pada Mahasiswa Program Studi Manajemen Fakultas Ekonomi Unika Widya Mandala Madiun. 474, 1-15.

Utari, F. D., \& Sukidjo, S. (2020). The Roles of Need for Achievement and Family Environment in Stimulating Entrepreneurial Interest through Self-Efficacy. Jurnal Economia, 16(2), 143-160. https://doi.org/10.21831/economia.v16i2.28725

Wartiovaara, M., Lahti, T., \& Wincent, J. (2019). The role of inspiration in entrepreneurship: Theory and the future research agenda. Journal of Business Research, 101(June), 548-554. https://doi.org/10.1016/j.jbusres.2018.11.035

Wirama, I. N. A., \& Wulanyani, N. M. S. (2016). Hubungan Bersyukur Dan Perilaku Prososial Terhadap Efikasi Diri Pada Pelaku Usaha Mikro, Kecil, Dan Menengah (UMKM) Kota Denpasar. Jurnal Psikologi Udayana, 3(2), 261-270. 